\title{
Long-chain unsaturated fatty acids reduce the transcriptional activity of the rat follicle-stimulating hormone $\beta$-subunit gene
}

\author{
Ryutaro MORIYAMA ${ }^{1)}$, Tsubasa YAMAZAKI ${ }^{1)}$, Takako KATO ${ }^{2)}$ and Yukio KATO ${ }^{2)}$ \\ 1) Laboratory of Environmental Physiology, Department of Life Science, School of Science and Engineering, Kinki University, \\ Osaka 577-8502, Japan \\ ${ }^{2)}$ Laboratory of Molecular Biology and Gene Regulation, Department of Life Science, School of Agriculture, Meiji \\ University, Kanagawa 214-8571, Japan
}

\begin{abstract}
Here, we assessed the effects of long-chain fatty acids (LCFAs) and the LCFA receptor agonist GW9508 on the transcription of the gonadotropin subunit genes Cga, Lhb and Fshb because LCFA receptor GPR120 was observed in mouse gonadotropes in our recent study. A transcription assay using L $\beta$ T2 cells demonstrated that LCFAs, oleic acid, $\alpha$-linolenic acid, docosahexaenoic acid and palmitate, repressed the expression of $C g a, L h b$, and $F s h b$ at concentrations between 50 and $100 \mu \mathrm{M}$. On the other hand, treatment with $10 \mu \mathrm{M}$ unsaturated LCFAs, oleic acid, $\alpha$-linolenic acid and docosahexaenoic acid, repressed only Fshb expression, while the same dose of a saturated LCFA, palmitate, had no effect on the expression of gonadotropin subunit genes. Furthermore, GW9508 did not affect promoter activity. Next, we examined deletion mutants of the upstream region of $F s h b$ and found that the upstream regulatory region (-2824 to $-2343 \mathrm{bp}$ ) of $F$ shb was responsible for the notable repression by $10 \mu \mathrm{M}$ unsaturated LCFAs. Our results suggest that the upstream region of $F$ shb is susceptible to unsaturated LCFAs. In addition, unsaturated LCFAs play a role in repressing Fshb expression through the distal -2824 to -2343 bp region, which might be independent of the LCFA receptor GPR120 pathway.
\end{abstract}

Key words: Follicle-stimulating hormone (FSH), Free fatty acid, Gonadotropin, Luteinizing hormone (LH), Pituitary

(J. Reprod. Dev. 62: 195-199, 2016)

G onadal function is regulated mainly at the hypothalamic level of the hypothalamic-pituitary-gonadal axis. However, increasing evidence suggests that gonadal function is controlled at the pituitary level. For example, cortisol has been reported to directly suppress pulsatile luteinizing hormone (LH) secretion from the pituitary in sheep $[1,2]$. Moreover, insulin, leptin, adiponectin, and other hormones are known to directly regulate LH secretion via gonadotropes [3-5]. These previous reports suggest that the synthesis and secretion of gonadotropic hormones can be directly regulated at the pituitary level by peripheral signals such as hormones. The pituitary gonadotropic hormones, LH and follicle-stimulating hormone (FSH), exist as heterodimers, comprised of a common glycoprotein $\alpha$-subunit (Cga) and their specific $\beta$-subunits, LH $\beta$ and FSH $\beta$, respectively. Genes encoding these three subunits are expressed in the pituitary gonadotropes, and several extracellular signals including GnRH, progesterone, estrogen, activin, and inhibin have been reported to regulate their expression via a specific upstream response element [6-14]. Therefore, characterization of response elements of gonadotropin subunit genes will help to determine the mechanisms underlying gonadotropin regulation at the pituitary level.

Long-chain fatty acids (LCFAs) may act as metabolic signals

Received: October 9, 2015

Accepted: December 30, 2015

Published online in J-STAGE: February 5, 2016

C2016 by the Society for Reproduction and Development

Correspondence: R. Moriyama (e-mail: mory@life.kindai.ac.jp)

This is an open-access article distributed under the terms of the Creative Commons Attribution Non-Commercial No Derivatives (by-nc-nd) License

$<\mathrm{http}: / /$ creativecommons.org/licenses/by-nc-nd/4.0/>. in the regulation of reproductive functions. This is supported by findings that peripheral or central lipoprivation suppresses pulsatile LH secretion $[15,16]$, and central exposure to linoleic acid increases Lhb mRNA expression levels in rats [17]. Interestingly, LCFAs are supposed to have some influence on the synthesis and secretion of gonadotropic hormones at the pituitary level, since a free fatty acid (FFA) cocktail directly increases Lhb mRNA levels and suppresses Fshb mRNA levels in the gonadotropic cell line L $\beta$ T2 [18] and linoleic acid increases LH release and Lhb mRNA levels in both L $\beta$ T2 cells and rat primary cultured pituitary cells [19]. Furthermore, LCFAs may induce these phenomena through LCFA receptor GPR120, which is known to be expressed in the gonadotropes of the mouse pituitary [20] and L $\beta$ T2 cells [19]. However, in previous studies with L $\beta$ T2 cells, the role of LCFAs in the gene expression and secretion of gonadotropic hormones has been examined using concentrations of LCFAs of several hundred micromolar. Therefore, the effect of lower than $100 \mu \mathrm{M}$ LCFAs on the gene expression and secretion of gonadotropic hormones is still unclear.

In the present study, we investigated the effects of concentrations of LCFAs below $100 \mu \mathrm{M}$ and a LCFA receptor agonist, GW9508, on the transcription of gonadotropin subunit genes, Cga, Lhb and Fshb, in L $\beta$ T2 cells and identified the gene regulatory region responsive to LCFAs.

\section{Materials and Methods}

\section{Cell culture}

The gonadotropic cell line L $\beta$ T2 (kindly provided by Dr PL Mellon) was maintained in monolayer cultures in Dulbecco's modified Eagle's 
medium (Life Technologies, Carlsbad, CA, USA) supplemented with $10 \%$ fetal bovine serum and $0.5 \%$ penicillin/streptomycin solution (Sigma-Aldrich, St. Louis, MO, USA) in a humidified 5\% $\mathrm{CO}_{2} / 95 \%$ air incubator at $37^{\circ} \mathrm{C}$.

At the time of the reporter assay, cells $\left(2 \times 10^{4}\right)$ were seeded in $100 \mu 1$ Opti-MEM (Life Technologies) per well of a 96-well plate, 24 $\mathrm{h}$ prior to transfection and maintained in a humidified $5 \% \mathrm{CO}_{2} / 95 \%$ air incubator at $37^{\circ} \mathrm{C}$.

\section{LCFA stock and working solutions}

The LCFAs, oleic acid, $\alpha$-linolenic acid, docosahexaenoic acid (DHA) and palmitate, were dissolved in $50 \%$ ethanol at $65^{\circ} \mathrm{C}$ to prepare $500 \mathrm{mM}$ stock solutions. Stock solutions and fatty acid-free bovine serum albumin (Sigma-Aldrich) in Opti-MEM were vortexed for $40 \mathrm{~min}$ and filtered to obtain a $10 \mathrm{mM}$ homogenous mixture in Opti-MEM containing 2\% bovine serum albumin.

\section{Reporter assay}

Upstream regions of the rat Cga (NC_005104.4), Lhb (NC_005100.4) and Fshb (NC_005102.4) genes were amplified using specific primer sets. The fragments were ligated into the secreted alkaline phosphatase (SEAP) plasmid vector pSEAP2-Basic (Clontech Laboratories, Palo Alto, CA, USA) as described previously [21-23]. The resulting reporter vectors contained the following gonadotropin subunit upstream regions: $-3793 /+37$ (Cga); -2930/+17 (Lhb); and $-2824 /+28,-2342 /+28,-1718 /+28,-1499 /+28,-1219 /+28,-970 /+28$, $-650 /+28,-346 /+28,-43 /+28(F \operatorname{shb})$.

Transfection was performed using $200 \mathrm{ng}$ DNA and $0.3 \mu \mathrm{l} \mathrm{FuGENE}$ HD (Roche Diagnostics, Basel, Switzerland) per well according to the protocol described in a previous study [24]. The cells were treated with an LCFA solution (10 $\mu 1$ per well) or the LCFA receptor agonist GW9508 at 7-8 h after transfection. After another $72 \mathrm{~h}$ of incubation, $5 \mu \mathrm{l}$ of culture medium from each well was assayed for SEAP activity using the Phospha-Light Reporter Gene Assay System (Applied Biosystems, Foster City, CA, USA) and Powerscan H1 microplate luminometer (DS Pharma Biomedical, Osaka, Japan) according to the manufacturers' protocols.

\section{Statistical analysis}

All values were expressed as the mean \pm SEM. Dunnett's method was used to analyze the effect of LCFAs or GW9508 on SEAP activity. P-values of $<0.05$ were considered significant.

\section{Results}

\section{Effect of LCFAs or GW9508 on transcriptional activation of gonadotropin subunit genes}

The promoter activity of $F \operatorname{shb}(-2824 /+28)$ was significantly repressed by not only treatment with both $100 \mu \mathrm{M}$ and $50 \mu \mathrm{M}$ DHA, oleic acid, $\alpha$-linolenic acid or palmitate but was also significantly repressed by $10 \mu \mathrm{M}$ DHA, oleic acid or $\alpha$-linolenic acid $(\mathrm{P}<0.05$; Fig. 1). On the other hand, the promoter activity of $C g a(-3793 /+37)$ was significantly repressed by treatment with $100 \mu \mathrm{M}$ DHA and by both $100 \mu \mathrm{M}$ and $50 \mu \mathrm{M}$ of oleic acid, $\alpha$-linolenic acid or palmitate, but it was not significantly repressed by $10 \mu \mathrm{M}$ LCFAs. Similar to the results for Cga, the promoter activity of Lhb $(-2930 /+17)$ was significantly repressed by treatment with $100 \mu \mathrm{M}$ DHA, oleic acid, $\alpha$-linolenic acid or palmitate and by treatment with $50 \mu \mathrm{M}$ palmitate.

Next, we determined whether LCFAs regulate the synthesis of gonadotropes through GPR120 at the pituitary level and found that the LCFA receptor agonist GW9508 did not affect promoter activity at any concentration of LCFA used in this study.

\section{Deletion analysis for the Fshb upstream region}

To confirm the marked repression of $F$ shb by $10 \mu \mathrm{M}$ oleic acid, $\alpha$-linolenic acid and DHA, deletion mutants of the upstream region of Fshb were examined using transfection and reporter gene assays. Oleic acid, $\alpha$-linolenic acid and DHA significantly repressed promoter activity of the -2824 to $+28 \mathrm{~b}$ region (Fig. 2 ). However, the $-2342 /+28,-1718 /+28,-1499 /+28,-1219 /+28,-970 /+28,-650 /+28$, $-346 /+28$, and $-43 /+28$ b regions lost the repression by oleic acid, $\alpha$-linolenic acid and DHA.

Figure 3 shows the locations of putative binding sites for transcription factors between the -2824 to -2343 b region of the rat Fshb upstream promoter, which responded to unsaturated LCFAs. Among the transcription factors binding to these sites, FOXJ1, GLU1, MSX, PITX1, PRRX2, RUNX1 and SOX2 were identified as those with expression in the murine pituitary gland.

\section{Discussion}

In this study, we determined the effect of LCFAs and the LCFA receptor agonist GW9508 on the transcription of gonadotropin hormone subunit genes, including $C g a, L h b$ and $F s h b$, and identified the gene regulatory regions that were responsive to LCFAs. As shown in Fig. 1, unsaturated LCFAs, DHA, oleic acid and $\alpha$-linolenic acid, markedly repressed the expression of $F s h b$ at a low concentration $(10 \mu \mathrm{M})$, while the saturated LCFA, palmitate, caused no apparent change in gonadotropin subunit gene expression at the same dose. Further, treatment with 50-100 $\mu$ M LCFAs repressed expression of the gonadotropin subunit genes $C g a, L h b$ and $F s h b$ (Fig. 1). In previous studies, the role of LCFAs on the transcription of gonadotropin hormone subunit genes has been examined using concentrations in the range of several hundred micromolars of LCFAs [17-19]. In this study, however, the low concentration of $10 \mu \mathrm{M}$ unsaturated LCFAs repressed the expression of $F s h b$. The concentration of nonesterified fatty acids in the rodent peripheral blood is in the hundreds of micromolar range $[25,26]$; therefore, the concentration of LCFAs used in this study is similar to the physiological level or even slightly lower than that recorded in rodent peripheral blood. These findings suggest that the transcription of Fshb is more sensitive or susceptible to unsaturated LCFAs compared with the previously reported concentration and that unsaturated LCFAs may be involved in the repression of Fshb transcription. Reproductive aging in women is characterized by shortening of the estrous cycle length [27], increased incidences of oocyte spindle aberrations or aneuploidy [28] and declining fertility [29]. Similar to humans, female rodents also show similar age-related physiological changes in reproductive function $[30,31]$. These changes are associated with elevated baseline levels of serum FSH in humans [32] and mice [33]. Interestingly, dietary administration of omega-3 polyunsaturated fatty acids such as DHA decreased serum baseline FSH levels and FSH response to GnRH without changing serum LH 


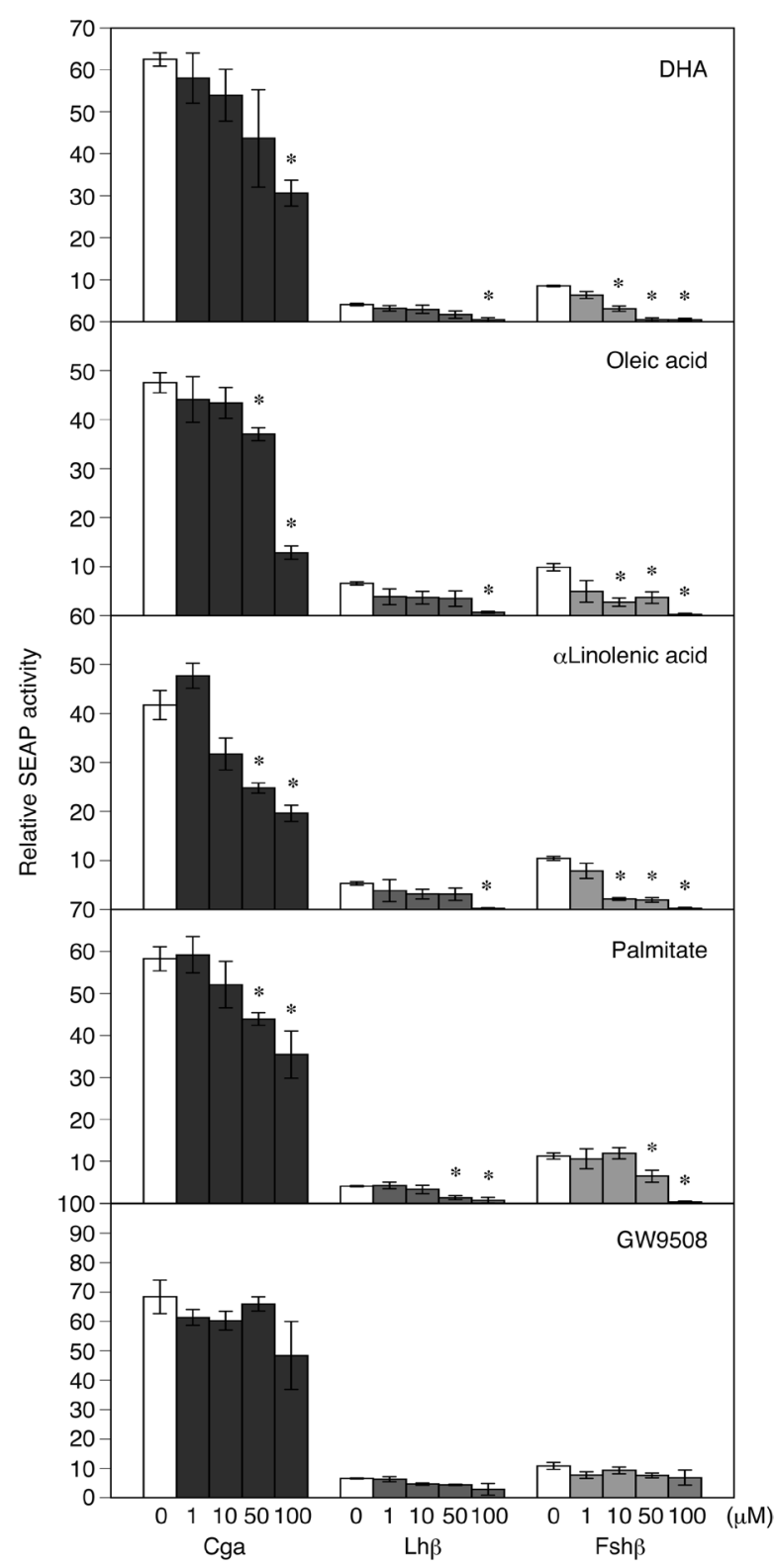

Fig. 1. Transient transfection assay of the rat gonadotropin subunit gene promoters in L $\beta \mathrm{T} 2$ cells with or without treatment with oleic acid, $\alpha$-linolenic acid, docosahexaenoic acid (DHA), palmitic acid or the long-chain fatty acid (LCFA) receptor agonist GW9508. Reporter constructs containing Cga (-3793/+37 b), Lhb $(-2930 /+17$ b) or Fshb $(-2824$ to +28 b) promoters fused with the secreted alkaline phosphatase (SEAP) gene in the pSEAP-Basic vector were transfected into L $\beta$ T2 cells. The cells were exposed to oleic acid, $\alpha$-linolenic acid, DHA, palmitic acid, or GW9508 $(1,10,50$ or $100 \mu \mathrm{M}) 7-8 \mathrm{~h}$ after transfection. An aliquot of the culture medium was used for the SEAP assay. SEAP activities are presented as the activity relative to that of the basic vector. Values are the mean \pm SEM of four independent experiments. ${ }^{*} \mathrm{P}<0.05$ $v s$. pSEAP2-Basic (Dunnett's method).

levels in reproductive-age women with normal body weights [34]. Furthermore, Nehra et al. [35] reported that dietary treatment with a diet rich in DHA prolonged reproductive lifespan and improved

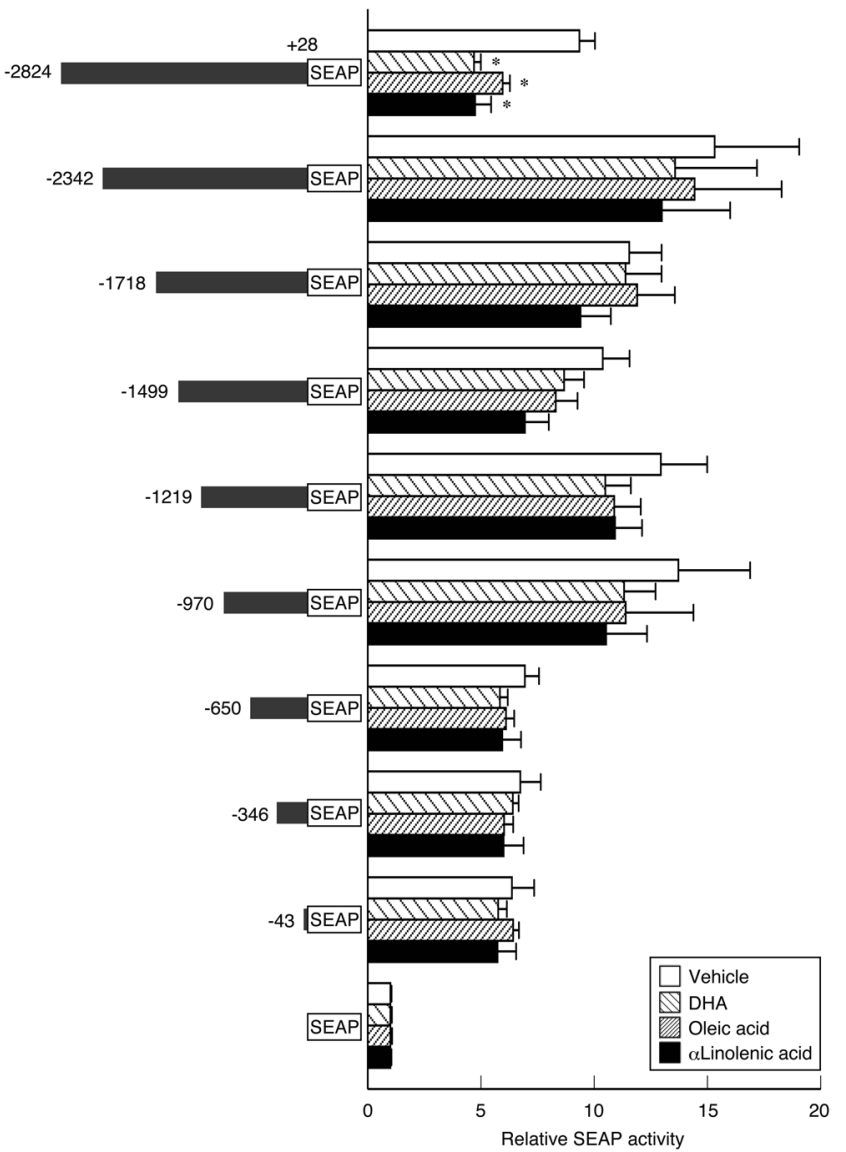

Fig. 2. Deletion analysis of the rat Fshb promoter region (-2824 to $+28 \mathrm{~b}$ regions) in L $\beta \mathrm{T} 2$ cells with or without treatment with $10 \mu \mathrm{M}$ unsaturated LCFAs oleic acid, $\alpha$-linolenic acid, or docosahexaenoic acid (DHA). On the left, reporter constructs are shown containing serial deletion mutants of the $F s h b$ promoter fused with the secreted alkaline phosphatase (SEAP) gene in the pSEAP2-Basic vector that were transfected into L $\beta$ T2 cells. On the right, SEAP activities are represented as the activity relative to that of the basic vector. Values are the mean \pm SEM for four independent experiments. * $\mathrm{P}<0.05$ vs. pSEAP2-Basic (Dunnett's method).

oocyte quality in mice. Thus, the effect of a low concentration of unsaturated LCFAs on the transcription of Fshb in this study may have identified a part of the mechanism of unsaturated LCFAs in the delay of female reproductive aging and improvement of oocyte quality.

A transfection assay using serial deletion mutants of the -2824 to $+28 \mathrm{~b}$ upstream region of $F s h b$ revealed that the $10 \mu \mathrm{M}$ unsaturated LCFA-responsive region for reducing $F s h b$ transcription is located in the -2824 to $-2343 \mathrm{~b}$ region (Fig. 2). Previous studies have shown that an FFA cocktail or linoleic acid reduces basal Fshb mRNA levels by disrupting the effects of activin on transcription of Fshb in L $\beta$ T2 cells $[17,18]$. L $\beta$ T2 cells have been reported to produce activin endogenously to maintain basal $F$ shb expression [36]. These previous results imply that the reduction of $F s h b$ transcription caused by unsaturated LCFAs via the -2824 to $-2343 \mathrm{~b}$ region in the present study may also be mediated by the disruption of activin effects on 


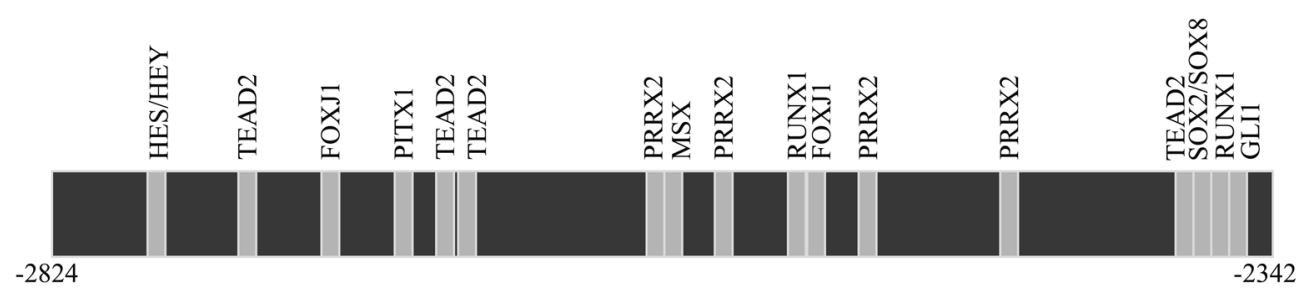

Fig. 3. Locations of gene transcription factor binding sites in the -2824 to $-2343 \mathrm{~b}$ region upstream of the $F$ sh $b$ promoter that was responsive to unsaturated LCFAs. Abbreviations of transcription factors: Forkhead box protein J1 (FOXJ1), glioma-associated oncogene homolog 1 (GLI1), hairy and enhancer of split (HES)/split-related with YRPW motif (HEY), Msh homeobox 1-like protein (MSX), paired-like homeodomain 1 (PITX1), paired related homeobox 2 (PRRX2), runt-related transcription factor 1 (RUNX1), sex-determining region Y-box 2 (SOX2)/sex-determining region Y-box 8 (SOX8), and TEA domain family member 2 (TEAD2).

Fshb expression. However, Suszko et al. [9] reported that the most activin-responsive domain of the rat $F$ shb promoter within the proximal promoter region was between -230 and $-199 \mathrm{~b}$. Therefore, the -2824 to $-2343 \mathrm{~b}$ region is a novel region for the transcriptional control with unsaturated LCFAs. It is not clear whether this region is an activin-responsive domain leading to the disruption of Fshb transcription by unsaturated LCFAs. Interestingly, the -2824 to -2343 b region may contain plural putative regulatory elements for diverse transcription factors, including Forkhead box protein J1 (FOXJ1), glioma-associated oncogene homolog 1 (GLI1), hairy and enhancer of split/split-related with YRPW motif, Msh homeobox 1-like protein (MSX), paired-like homeodomain 1 (PITX1), paired related homeobox 2 (PRRX2), runt-related transcription factor 1 (RUNX1), sex-determining region Y-box 2 (SOX2)/sex-determining region Y-box 8, and TEA domain family member 2 (Fig. 3). In particular, FOXJ1, GLI1, MSX, PITX1, PRRX2, RUNX1, and SOX2 are expressed in the murine pituitary gland [37-42]. Therefore, unsaturated LCFAs may directly and/or indirectly modulate the binding of any of these factors. Indeed, in a previous study [43], PITX1 was observed to regulate murine and human $F$ shb transcription. Nevertheless, the role of the -2824 to -2343 b upstream region of rat Fshb and its molecular mechanism for the suppression by unsaturated LCFAs will need to be clarified by further investigations.

We hypothesized that LCFAs directly regulate the synthesis of gonadotropes through GPR120 at the pituitary level, because GPR120 expression has been observed in the gonadotropes of the mouse pituitary [20]. To test our hypothesis, the LCFA receptor agonist GW9508 was used. However, treatment with GW9508 did not affect gonadotropin subunit gene expression at the LCFA doses used in our study, although LCFAs repressed the promoter activity of gonadotropin subunit genes in L $\beta$ T2 pituitary gonadotropic cells (Fig. 1). The dose of GW9508 used in this study was similar to that used in a previous study in which L $\beta$ T2 cells were exposed to GW9508 [19] and induced an agonistic effect on GRP120 [44]. These results indicate that the reduction of transcription of $F s h b$ is likely mediated by the $\beta$-oxidation products of unsaturated LCFAs and/or by the direct or indirect action of unsaturated LCFAs on the Fshb transcriptional regulatory mechanisms.

The present results showing that LCFAs repressed the transcription of $C g a$ and $L h b$ (Fig. 1) contradict the results of previous studies. Sharma et al. [18] reported that an FFA cocktail induced an increase in $L h b$ mRNA levels in L $\beta T 2$ cells. Garrel et al. $[17,19]$ reported that linoleic acid treatment induced an increase in the $L h b$ mRNA levels, while it had no effect on Cga mRNA levels in L $\beta$ T2 cells or rat anterior pituitary cells. The inconsistency may depend on the difference in experimental methods used. Previous studies have demonstrated the effect of LCFAs on gonadotropin hormone subunit mRNA levels using real-time PCR, whereas we investigated the function of the enhancer/promoter elements of the gonadotropin genes using the SEAP reporter gene assay system. We only examined the region $\sim 3.8 \mathrm{~kb}$ upstream of the rat gonadotropic subunit genes. In the SEAP reporter gene assay system, it may be necessary to analyze additional upstream regions to determine the gonadotropin transcription control mechanism by LCFAs. The upstream regions of $C g a$ and $L h b$ examined in this study may lack the specific response regions for LCFAs, in contrast to the results measured for Cga and $L h b$ mRNA in the previous studies. The evidence concerning the LCFA response in the transcription of Cga and Lhb is not conclusive.

In conclusion, the promoter assay using reporter vectors revealed that the transcription of $F_{s} h b$ was susceptible to unsaturated LCFAs compared with the transcription of Cga and Lhb. Furthermore, the unsaturated LCFAs, DHA, oleic acid and $\alpha$-linolenic acid, exhibited repressive regulation of rat $F s h b$ expression at -2824 and -2343 b of the 5 '-flanking region and might be independent of the GPR120 pathway.

\section{Acknowledgments}

We thank Dr PL Mellon for providing us with L $\beta$ T2 cells. We also thank Dr Takao Susa for technical assistance and advice. This work was supported in part by a Japan Society for the Promotion of Science KAKENHI Grant (23780282 and 26450452 awarded to RM and 26292166 to YK) and Kinki University (RK-058 awarded to RM). This study was also supported by the Meiji University International Institute for BioResource Research (MUIIR) and by Research Funding for the Computational Software Support Program from Meiji University.

\section{References}

1. Pierce BN, Stackpole CA, Breen KM, Clarke IJ, Karsch FJ, Rivalland ET, Turner AI, Caddy DJ, Wagenmaker ER, Oakley AE, Tilbrook AJ. Estradiol enables cortisol to act directly upon the pituitary to suppress pituitary responsiveness to GnRH in sheep. Neuroendocrinology 2009; 89: 86-97. [Medline] [CrossRef]

2. Breen KM, Davis TL, Doro LC, Nett TM, Oakley AE, Padmanabhan V, Rispoli LA, Wagenmaker ER, Karsch FJ. Insight into the neuroendocrine site and cellular mecha- 
nism by which cortisol suppresses pituitary responsiveness to gonadotropin-releasing hormone. Endocrinology 2008; 149: 767-773. [Medline] [CrossRef]

3. Avelino-Cruz JE, Flores A, Cebada J, Mellon PL, Felix R, Monjaraz E. Leptin increases L-type $\mathrm{Ca}^{2+}$ channel expression and GnRH-stimulated LH release in LbetaT2 gonadotropes. Mol Cell Endocrinol 2009; 298: 57-65. [Medline] [CrossRef]

4. Lu M, Tang Q, Olefsky JM, Mellon PL, Webster NJ. Adiponectin activates adenosine monophosphate-activated protein kinase and decreases luteinizing hormone secretion in LbetaT2 gonadotropes. Mol Endocrinol 2008; 22: 760-771. [Medline] [CrossRef]

5. Rodriguez-Pacheco F, Martinez-Fuentes AJ, Tovar S, Pinilla L, Tena-Sempere M, Dieguez C, Castaño JP, Malagon MM. Regulation of pituitary cell function by adiponectin. Endocrinology 2007; 148: 401-410. [Medline] [CrossRef]

6. Fortin J, Ongaro L, Li Y, Tran S, Lamba P, Wang Y, Zhou X, Bernard DJ. Activin signaling in gonadotropes: What does the FOX say to the SMAD? Mol Endocrinol 2015; 29: 963-977. [Medline] [CrossRef]

7. Tran S, Lamba P, Wang Y, Bernard DJ. SMADs and FOXL2 synergistically regulate murine FSHbeta transcription via a conserved proximal promoter element. Mol Endocrinol 2011; 25: 1170-1183. [Medline] [CrossRef]

8. Ciccone NA, Lacza CT, Hou MY, Gregory SJ, Kam KY, Xu S, Kaiser UB. A composite element that binds basic helix loop helix and basic leucine zipper transcription factors is important for gonadotropin-releasing hormone regulation of the follicle-stimulating hormone beta gene. Mol Endocrinol 2008; 22: 1908-1923. [Medline] [CrossRef]

9. Suszko MI, Balkin DM, Chen Y, Woodruff TK. Smad3 mediates activin-induced transcription of follicle-stimulating hormone beta-subunit gene. Mol Endocrinol 2005; 19: 1849-1858. [Medline] [CrossRef]

10. Coss D, Jacobs SB, Bender CE, Mellon PL. A novel AP-1 site is critical for maximal induction of the follicle-stimulating hormone beta gene by gonadotropin-releasing hormone. J Biol Chem 2004; 279: 152-162. [Medline] [CrossRef]

11. O'Conner JL, Wade MF, Prendergast P, Edwards DP, Boonyaratanakornkit V, Mahesh VB. A 361 base pair region of the rat FSH-beta promoter contains multiple progesterone receptor-binding sequences and confers progesterone responsiveness. Mol Cell Endocrinol 1997; 136: 67-78. [Medline] [CrossRef]

12. Bailey JS, Rave-Harel N, McGillivray SM, Coss D, Mellon PL. Activin regulation of the follicle-stimulating hormone beta-subunit gene involves Smads and the TALE homeodomain proteins Pbx1 and Prep1. Mol Endocrinol 2004; 18: 1158-1170. [Medline] [CrossRef]

13. Miller CD, Miller WL. Transcriptional repression of the ovine follicle-stimulating hormone-beta gene by 17 beta-estradiol. Endocrinology 1996; 137: 3437-3446. [Medline]

14. Yoshida S, Kato T, Nishimura N, Kanno N, Chen M, Ueharu H, Nishihara H, Kato Y. Transcription of follicle-stimulating hormone subunit genes is modulated by porcine LIM homeobox transcription factors, LHX2 and LHX3. J Reprod Dev 2016 (in press) http://doi. org/10.1262/jrd.2015-163

15. Sajapitak S, Iwata K, Shahab M, Uenoyama Y, Yamada S, Kinoshita M, Bari FY, I'Anson H, Tsukamura H, Maeda K. Central lipoprivation-induced suppression of luteinizing hormone pulses is mediated by paraventricular catecholaminergic inputs in female rats. Endocrinology 2008; 149: 3016-3024. [Medline] [CrossRef]

16. Shahab M, Sajapitak S, Tsukamura H, Kinoshita M, Matsuyama S, Ohkura S, Yamada S, Uenoyama Y, I'Anson H, Maeda K. Acute lipoprivation suppresses pulsatile luteinizing hormone secretion without affecting food intake in female rats. $J$ Reprod Dev 2006; 52: 763-772. [Medline] [CrossRef]

17. Garrel G, Simon V, Denoyelle C, Ishaq M, Rouch C, Dairou J, Magnan C, Migrenne S, Cruciani-Guglielmacci C, Cohen-Tannoudji J. Unsaturated fatty acids disrupt Smad signaling in gonadotrope cells leading to inhibition of $\mathrm{FSH} \beta$ gene expression. Endocrinology 2014; 155: 592-604. [Medline] [CrossRef]

18. Sharma S, Morinaga H, Hwang V, Fan W, Fernandez MO, Varki N, Olefsky JM, Webster NJ. Free fatty acids induce Lhb mRNA but suppress Fshb mRNA in pituitary L $\beta$ T2 gonadotropes and diet-induced obesity reduces FSH levels in male mice and disrupts the proestrous LH/FSH surge in female mice. Endocrinology 2013; 154: 2188-2199. [Medline] [CrossRef]

19. Garrel G, Simon V, Denoyelle C, Cruciani-Guglielmacci C, Migrenne S, Counis R, Magnan C, Cohen-Tannoudji J. Unsaturated fatty acids stimulate LH secretion via novel PKCepsilon and -theta in gonadotrope cells and inhibit GnRH-induced LH release. Endocrinology 2011; 152: 3905-3916. [Medline] [CrossRef]

20. Moriyama R, Deura C, Imoto S, Nose K, Fukushima N. Expression of the long-chain fatty acid receptor GPR120 in the gonadotropes of the mouse anterior pituitary gland. Histochem Cell Biol 2015; 143: 21-27. [Medline] [CrossRef]

21. Ishikawa A, Kato T, Susa T, Sano A, Kato Y. Molecular cloning and characterization of porcine homeodomain transcription factor Msx1. J Reprod Dev 2009; 55: 278-282. [Medline] [CrossRef]

22. Aikawa S, Susa T, Sato T, Kitahara K, Kato T, Kato Y. Transcriptional activity of the 5 ' upstream region of the porcine glycoprotein hormone alpha subunit gene. $J$ Reprod Dev 2005; 51: 117-121. [Medline] [CrossRef]

23. Kato T, Ishikawa A, Yoshida S, Sano Y, Kitahara K, Nakayama M, Susa T, Kato Y.
Molecular cloning of LIM homeodomain transcription factor Lhx2 as a transcription factor of porcine follicle-stimulating hormone beta subunit (FSH $\beta$ ) gene. J Reprod Dev 2012; 58 147-155. [Medline] [CrossRef]

24. Susa T, Kato T, Kato Y. Reproducible transfection in the presence of carrier DNA using FuGENE6 and Lipofectamine2000. Mol Biol Rep 2008; 35: 313-319. [Medline] [CrossRef]

25. Karpe F, Dickmann JR, Frayn KN. Fatty acids, obesity, and insulin resistance: time for a reevaluation. Diabetes 2011; 60: 2441-2449. [Medline] [CrossRef]

26. Goncalves de Albuquerque CF, Burth P, Younes Ibrahim M, Garcia DG, Bozza PT, Castro Faria Neto HC, Castro Faria MV. Reduced plasma nonesterified fatty acid levels and the advent of an acute lung injury in mice after intravenous or enteral oleic acid administration. Mediators Inflamm 2012; 2012: 601032. [Medline]

27. Lenton EA, Landgren BM, Sexton L, Harper R. Normal variation in the length of the follicular phase of the menstrual cycle: effect of chronological age. Br J Obstet Gynaecol 1984; 91: 681-684. [Medline] [CrossRef]

28. Jones KT. Meiosis in oocytes: predisposition to aneuploidy and its increased incidence with age. Hum Reprod Update 2008; 14: 143-158. [Medline] [CrossRef]

29. Heffner LJ. Advanced maternal age-how old is too old? $N$ Engl J Med 2004; 351 1927-1929. [Medline] [CrossRef]

30. Gosden RG, Laing SC, Felicio LS, Nelson JF, Finch CE. Imminent oocyte exhaustion and reduced follicular recruitment mark the transition to acyclicity in aging C57BL/6J mice. Biol Reprod 1983; 28: 255-260. [Medline] [CrossRef]

31. Wu JM, Zelinski MB, Ingram DK, Ottinger MA. Ovarian aging and menopause: current theories, hypotheses, and research models. Exp Biol Med (Maywood) 2005; 230: 818-828. [Medline]

32. Klein NA, Battaglia DE, Fujimoto VY, Davis GS, Bremner WJ, Soules MR. Reproductive aging: accelerated ovarian follicular development associated with a monotropic follicle-stimulating hormone rise in normal older women. J Clin Endocrinol Metab 1996 81: 1038-1045. [Medline]

33. Bernstein LR, Mackenzie AC, Kraemer DC, Morley JE, Farr S, Chaffin CL, Merchenthaler I. Shortened estrous cycle length, increased FSH levels, FSH variance, oocyte spindle aberrations, and early declining fertility in aging senescence-accelerated mouse prone-8 (SAMP8) mice: concomitant characteristics of human midlife female reproductive aging. Endocrinology 2014; 155: 2287-2300. [Medline] [CrossRef]

34. Al-Safi ZA, Liu H, Carlson NE, Chosich J, Harris M, Bradford AP, Robledo C, Eckel RE, Polotsky AJ. Omega-3 fatty acid supplementation lowers serum FSH in norma weight but not obese women. J Clin Endocrinol Metab 2016; 101: 324-333. [Medline]

35. Nehra D, Le HD, Fallon EM, Carlson SJ, Woods D, White YA, Pan AH, Guo L, Rodis SJ, Tilly JL, Rueda BR, Puder M. Prolonging the female reproductive lifespan and improving egg quality with dietary omega-3 fatty acids. Aging Cell 2012; 11: 1046-1054. [Medline] [CrossRef]

36. Pernasetti F, Vasilyev VV, Rosenberg SB, Bailey JS, Huang HJ, Miller WL, Mellon PL. Cell-specific transcriptional regulation of follicle-stimulating hormone-beta by activin and gonadotropin-releasing hormone in the LbetaT2 pituitary gonadotrope cell model. Endocrinology 2001; 142: 2284-2295. [Medline]

37. Nishimura N, Ueharu H, Nishihara H, Shibuya S, Yoshida S, Higuchi M, Kanno N, Horiguchi K, Kato T, Kato Y. Search for regulatory factors of the pituitary-specific transcription factor PROP1 gene. J Reprod Dev 2015; 62: 93-102. [Medline]

38. Lampichler K, Ferrer P, Vila G, Lutz MI, Wolf F, Knosp E, Wagner L, Luger A, Baumgartner-Parzer S. The role of proto-oncogene GLI1 in pituitary adenoma formation and cell survival regulation. Endocr Relat Cancer 2015; 22: 793-803. [Medline] [CrossRef]

39. MacKenzie A, Ferguson MW, Sharpe PT. Hox-7 expression during murine craniofacial development. Development 1991; 113: 601-611. [Medline]

40. Szeto DP, Ryan AK, O'Connell SM, Rosenfeld MG. P-OTX: a PIT-1-interacting homeodomain factor expressed during anterior pituitary gland development. Proc Natl Acad Sci USA 1996; 93: 7706-7710. [Medline] [CrossRef]

41. Susa T, Kato T, Yoshida S, Yako H, Higuchi M, Kato Y. Paired-related homeodomain proteins Prx 1 and Prx2 are expressed in embryonic pituitary stem/progenitor cells and may be involved in the early stage of pituitary differentiation. J Neuroendocrinol 2012; 24 1201-1212. [Medline] [CrossRef]

42. Breen KM, Thackray VG, Coss D, Mellon PL. Runt-related transcription factors impai activin induction of the follicle-stimulating hormone $\beta$-subunit gene. Endocrinology 2010; 151: 2669-2680. [Medline] [CrossRef]

43. Lamba P, Khivansara V, D'Alessio AC, Santos MM, Bernard DJ. Paired-like homeodomain transcription factors 1 and 2 regulate follicle-stimulating hormone beta-subunit transcription through a conserved cis-element. Endocrinology 2008; 149: 3095-3108. [Medline] [CrossRef]

44. Briscoe CP, Peat AJ, McKeown SC, Corbett DF, Goetz AS, Littleton TR, McCoy DC, Kenakin TP, Andrews JL, Ammala C, Fornwald JA, Ignar DM, Jenkinson S. Pharmacological regulation of insulin secretion in MIN6 cells through the fatty acid receptor GPR40: identification of agonist and antagonist small molecules. Br J Pharmacol 2006 148: 619-628. [Medline] [CrossRef] 